\title{
Diel and seasonal variation of a molluscan taxocoenosis associated with a Zostera marina bed in southern Spain (Alboran Sea)
}

\author{
Jose L. Rueda $\cdot$ Javier Urra $\cdot$ Carmen Salas
}

Received: 29 September 2007 / Revised: 18 January 2008 / Accepted: 18 February 2008 / Published online: 20 March 2008 (C) Springer-Verlag and AWI 2008

\begin{abstract}
The diel and seasonal variation of molluscs living in a Zostera marina bed (12-14 $\mathrm{m}$ depth) from southern Spain have been studied for one year using a small Agassiz trawl for collecting the samples $\left(222 \mathrm{~m}^{2}\right)$. The frequent and dominant species were very similar in both diurnal and nocturnal samples, including mainly gastropods such as Jujubinus striatus, Nassarius pygmaeus, Mitrella minor, Calliostoma planatum, Rissoa membranacea or Smaragdia viridis. Nevertheless, a significant increase of abundance of scavengers (e.g. Nassarius spp.) and carnivores (e.g. cephalopods) was registered in nocturnal samples. The abundance was maximal in spring and summer in diurnal and nocturnal samples and also in autumn for nocturnal ones, displaying significantly higher values in nocturnal samples. The species richness, diversity and evenness displayed a similar seasonal trend for diurnal and nocturnal samples, with maximum values during summer months. Monthly variation of the molluscan composition (species presenceabsence data) was more acute than diel variation, according to the Cluster, MDS and ANOSIM results. Nevertheless, both monthly and diel changes in the structure (species abundance data) of the molluscan taxocoenosis were
\end{abstract}

Communicated by L. Gimenez.

Electronic supplementary material The online version of this article (doi:10.1007/s10152-008-0111-1) contains supplementary material, which is available to authorized users.

J. L. Rueda $(\bowtie) \cdot$ J. Urra $\cdot$ C. Salas $(\bowtie)$

Departamento de Biología Animal,

Universidad de Málaga, Campus de Teatinos s/n,

29071 Malaga, Spain

e-mail: biologiamarina@uma.es

C. Salas

e-mail: casanova@uma.es important throughout the year. Diel changes in the structure of the molluscan fauna are related to an increase of abundance of some species at nighttime due to vertical movements from the sediment to the shoots or along them (e.g. J. striatus, Nassarius spp.) or due to horizontal movements from adjacent habitats (e.g. cephalopods). Nevertheless, some species such as Rissoa spp. or Bittium spp. stay on the leaves of $Z$. marina during day as well as nighttime.

Keywords Diversity - Temporal dynamics . Mediterranean Sea $\cdot$ Nocturnal $\cdot$ Seagrass

\section{Introduction}

Seagrass beds are among the most endangered habitats and their regression worldwide may affect both the local and global biodiversity (Short and Neckles 1999; Duarte 2002). The rich faunistic and floristic biodiversity from this type of habitat is explained by the higher availability of (1) microhabitats and substrate types (Boström and Bonsdorff 1997; Hemminga and Duarte 2000; Green and Short 2003), (2) food sources (Mazzella et al. 1995; Hily and Bouteille 1999; Kharlamenko et al. 2001; Green and Short 2003), and (3) shelter against predators (Irlandi 1994, 1997) in comparison with unvegetated bottoms. Therefore, seagrass beds and their associated communities are interesting systems to be studied.

The molluscan fauna associated with the eelgrass Zostera marina has received much attention in different locations in Europe. Along the Atlantic coasts, the molluscan fauna associated with eelgrass beds is well known (Jacobs and Huisman 1982; Jacobs et al. 1983; Currás et al. 1993; Fredriksen et al. 2005; Boström and Bonsdorff 1997, 2000; Frost et al. 1999; Hily and Bouteille 1999). 
In the Mediterranean, the molluscan fauna associated with $Z$. marina has been rarely studied, probably because this seagrass is quite scarce and is mostly limited to shallow coastal lagoons (Ledoyer 1966; Mars 1966; Çinar et al. 1998; Sfriso et al. 2001). In the Alboran Sea (western Mediterranean), $Z$. marina beds are close to the southern limit of its distribution in the eastern Atlantic basin. In this area, eelgrass beds occur in open bays between 5 and 17 meters depth (BañaresEspaña et al. 2002) and its associated fauna has been scarcely studied (García-Raso et al. 2004, Arroyo et al. 2006).

In temperate areas, Z. marina displays variation in shoot length and density along an annual cycle, leading to a change in the canopy (Marbà et al. 1996; Boström et al. 2003; Guidetti 2000; Guidetti et al. 2002; Rueda et al. 2008). Therefore, an intra-annual variation of the associated molluscan assemblage is expected. Some previous studies on molluscan fauna associated with shallow eelgrass beds (intertidal $-7 \mathrm{~m}$ depth) included information on these seasonal changes (Atlantic Ocean: Jacobs et al. 1983; Currás et al. 1993; Quintas 2005; Mediterranean Sea: Çinar et al. 1998; Sfriso et al. 2001). However, this type of information is still scarce for the associated malacofauna of deeper Z. marina beds (5-17 $\mathrm{m}$ depth), such as those located in southern Spain (Arroyo et al. 2006). In addition to seasonal changes, there is a diel variability related to short-term movements of the animals within a day and night cycle along the seagrass shoots or from adjacent habitats. Information on diel variation of molluscan taxocoenoses is scarce (Templado 1982; Le Loeuff and Intès 1999; Mattila et al. 1999; Sánchez-Jerez et al. 1999) in comparison with that available for organisms with higher mobility (Fish: Gray et al. 1998; Griffiths 2001; Petrakis et al. 2001; Guest et al. 2003; Crustaceans: Vance 1992; Vance et al. 1994; Guest et al. 2003; García-Raso et al. 2006). The diel variation of a molluscan taxocoenosis associated with $Z$. marina beds has been studied only for shallower meadows in North America but no information on its seasonal dynamics was given (Mattila et al. 1999).

The main objectives of this investigation were to study both the temporal (monthly) and diel (diurnal/nocturnal) variation of the molluscan fauna associated with deep $Z$. marina beds in the Alboran Sea. We expected (1) a high biodiversity of molluscs, (2) seasonal variation due to the vegetated type of habitat and (3) an increase of species richness and abundance in the nocturnal samples.

\section{Materials and methods}

Study area

The sampling site is located on the Spanish coast of the Alboran Sea (western Mediterranean) (Fig. 1). This study was

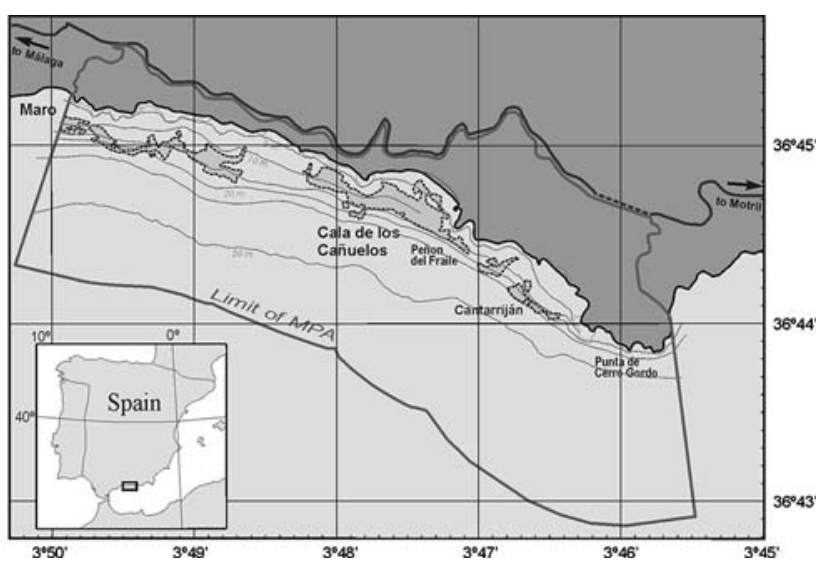

Fig. 1 Location of Cañuelo Bay (Cala de los Cañuelos; sampling site) within the marine protected area of Acantilados de Maro-Cerro Gordo in the littoral of Granada and Malaga (southern Spain). (Adapted from Bañares-España et al. 2002). Shaded areas represent the approximate extension of Zostera marina beds in the period 2000-2001

carried out in Cañuelo Bay (Cala de los Cañuelos) $\left(36^{\circ}\right.$ $44.5^{\prime} \mathrm{N}-03^{\circ} 47.6^{\prime} \mathrm{W}$ ), which is included in the Marine Protected Area (MPA) "Paraje Natural Acantilados de MaroCerro Gordo", located between the provinces of Malaga and Granada. Eelgrass beds are distributed along the coastline of this MPA at depths between 5 and 17 metres. The maximum coverage (97.3\%) and shoot density occur in front of Cañuelo Bay at 12-14 meters depth where there was the largest Z. marina bed (ca. 38.8 hectares) (Bañares-España et al. 2002). The dynamics of $Z$. marina shows a temporal trend, with highest shoot density (428 shoots $\mathrm{m}^{-2}$ ) and shoot height ( $33.94 \pm 3.72 \mathrm{~cm} ; n=172$ shoots) in summer and lowest shoot density (204 shoots $\mathrm{m}^{-2}$ ) and shoot height $(22.4 \pm 2.77 \mathrm{~cm} ; n=156$ shoots) in autumn-winter (Rueda et al. 2008). The sediment covered by this seagrass is muddy fine sand (15-20\% of mud), with an organic matter content between $2.5-3 \%$. This deep subtidal eelgrass bed is located in an open bay and not in shallow lagoons as most Mediterranean eelgrass beds are (Laugier et al. 1999; Guidetti 2000), therefore, in this case the tidal influence and the wave action is minimal. The water temperature ranges from $15^{\circ} \mathrm{C}$ in winter to $21^{\circ} \mathrm{C}$ in summer. The salinity remains almost constant along the year due to the low fresh water input in the area (e.g. absence of rivers and streams). Nevertheless, the salinity may reach up to 37.2 psu in summer, with similar values from the surface to 25 meters depth.

Samples collection and laboratory procedures

A small Agassiz trawl $(72 \mathrm{~cm}$ width, $30 \mathrm{~cm}$ height, mesh size: $3 \mathrm{~mm}$ ) was used for collecting the faunistic samples in order to minimize the impact on the $Z$. marina plants. The sampling area covered in each sample was $222 \mathrm{~m}^{2}$, resulting from the width of the Agassiz trawl and the boat speed 
of $1 \mathrm{knot} \mathrm{h}^{-1}$ in $10 \mathrm{~min}$. Samples were collected during daytime (11-13 h) and nighttime (23-24 h) between March 2000 and 2001. In March 2000 only the diurnal sample could be collected; diurnal and nocturnal samples could not be collected within the same day in April 2000 and February 2001. In spite of the mesh size, the underestimation of the juvenile abundance was minimized as a result of the usually large amount of material collected, which stretched the net and therefore clogged the mesh size.

Each sample of fauna collected with the Agassiz trawl was sieved over mesh sizes of 10, 7, 5, 3 and $1 \mathrm{~mm}$, storing each size fraction in $70 \%$ ethanol. This was done in order to facilitate sorting at the species level, and to help to separate juveniles from adults of some species. Each mollusc species was identified and their individuals counted in each sample. All the material collected has been deposited in the Departamento de Biología Animal from the Universidad de Málaga (Spain).

\section{Data analysis}

The characterization of the species was done according to (1) the species abundance or density (222 $\mathrm{m}^{2}$ sampled area), (2) the Frequency index as the percentage of samples in which the species is present, \%F, (Glémarec 1969) and (3) the Dominance index as the percentage of individuals of one particular species from the total collected, \%D (Glémarec 1969).

The characterization of the taxocoenosis was done according to the species richness (number of species per sample), the Shannon-Wiener diversity index (Krebs 1989), Evenness index (Pielou 1969) and the Heterogeneity index, between contiguous monthly samples and between day and night within the same month (Margalef 1956 after modifications by Niell and Rucabado 1981). Statistical differences of monthly values of abundance and ecological indices from day and night samples were tested with a two-factor ANOVA (Underwood 1997), in order to test the significance of the diel (Factor diel) and the seasonal variation (Factor season). In this case, the factors included comparisons of the diurnal samples $(n=13)$ versus nocturnal ones ( $n=12$ ) and seasonal samples of spring ( $n=3$ diurnal and 3 nocturnal) versus summer ( $n=3$ diurnal and 3 nocturnal) versus autumn ( $n=3$ diurnal and 3 nocturnal) versus winter ( $n=4$ diurnal and 3 nocturnal). The density of the taxocenosis or single species/groups has also been compared using one-factor ANOVA, according to diurnal-nocturnal variation or to seasonal groupings (e.g. spring, summer and autumn vs. winter). A Barlett test was done in order to verify the homogeneity of variances prior to ANOVA analyses. These statistical procedures were performed using the software SYSTAT 9 (SPSS).

The similarity between samples was evaluated using both qualitative (presence/absence) and quantitative data (fourth root transformed abundance data) of species per sample. The similarity index of Bray and Curtis (1957) was used as a meaningful and robust measure (Clarke 1993) for obtaining a cluster analysis (UPGMA method) and a MDS ordination with both qualitative and quantitative data. As a control, the similarity index of Sorensen-Dice was also performed using qualitative data, in order to give double weight to positive co-occurrences of species in the samples. The latter index yielded results, which were very similar to those using the Bray-Curtis similarity index with qualitative data. For this reason, only those results obtained with the Sorensen-Dice index are detailed hereafter. Molluscan assemblages were also compared using an analysis of similarities, ANOSIM (Clarke and Green 1988) in relation to (1) diurnal ( $n=13$ samples) versus nocturnal samples $(n=12)$ or (2) cold, autumn and winter $(n=7$ diurnal and 6 nocturnal samples) versus warm, spring and summer months $(n=6$ diurnal and 6 nocturnal samples). This analysis is a nonparametric analogue to a multivariate analysis of variance (MANOVA) and compares ranked similarities between and within groups, which were selected a priori according to the studied factors (day vs. night samples, cold vs. warm season samples). Finally, a SIMPER (SIMilarity PERcentage) analysis was done in order to know the contribution of the species in the similarity/dissimilarity within and between the same groups of samples. All these multivariate analyses were executed using the PRIMER software from Plymouth Marine Laboratory, UK (Clarke and Warwick 1994).

\section{Results}

Composition and structure of the assemblages

A total of 118 species were identified, of which 88 spp. were collected in the diurnal samples and 102 spp. in the nocturnal ones. From the total collected, gastropods represented the main group (81 spp.), followed by bivalves (33 spp.) and cephalopods (4 spp.). A total of 16 species $(13.56 \%)$ were restricted to the diurnal samples and 30 species $(24.58 \%)$ were restricted to the nocturnal samples.

A total of 366,121 individuals were collected, with 109,152 in diurnal samples and 256,969 in nocturnal samples. The molluscan fauna was mainly composed by gastropods (99\% of total collected) in both diurnal and nocturnal samples. The trochids were the most abundant family $(66.03 \%)$, followed by nassarids $(19.30 \%)$ and rissoids $(2.53 \%)$. The bivalves collected represented a low percentage (around $0.3-0.6 \%$ ) and were mainly epifaunal species. The cephalopods, with 36 individuals, represented a low percentage $(0.01 \%)$ of the molluscan taxocoenosis.

The top-twenty dominant species of the diurnal and nocturnal samples are indicated in Table 1. In both 
Table 1 Top-20 dominant (\%D) and frequent (\%F) molluscan species in the global (diurnal + nocturnal), diurnal and nocturnal assemblages in a Zostera marina bed (12-14 m depth)

\begin{tabular}{|c|c|c|c|c|c|c|c|c|}
\hline \multicolumn{3}{|l|}{ Global } & \multicolumn{3}{|l|}{ Diurnal } & \multicolumn{3}{|l|}{ Nocturnal } \\
\hline Species & $N$ & $\% \mathrm{D}$ & Species & $N$ & $\% \mathrm{D}$ & Species & $N$ & $\% \mathrm{D}$ \\
\hline Jujubinus striatus & 241712 & 66.02 & Jujubinus striatus & 86804 & 79.52 & Jujubinus striatus & 154908 & 60.28 \\
\hline Nassarius pygmaeus & 68456 & 18.70 & Mitrella minor & 6139 & 5.62 & Nassarius pygmaeus & 64080 & 24.94 \\
\hline Mitrella minor & 28011 & 7.65 & Nassarius pygmaeus & 4376 & 4.01 & Mitrella minor & 21872 & 8.51 \\
\hline Calliostoma planatum & 8189 & 2.24 & Rissoa membranacea & 3417 & 3.13 & Calliostoma planatum & 5543 & 2.16 \\
\hline Rissoa membranacea & 6425 & 1.75 & Calliostoma planatum & 2646 & 2.42 & Rissoa membranacea & 3008 & 1.17 \\
\hline Bittium reticulatum & 3227 & 0.88 & Bittium reticulatum & 2092 & 1.92 & Nassarius reticulatus & 1160 & 0.45 \\
\hline Smaragdia viridis & 1795 & 0.49 & Rissoa monodonta & 807 & 0.74 & Bittium reticulatum & 1135 & 0.44 \\
\hline Rissoa monodonta & 1551 & 0.42 & Smaragdia viridis & 677 & 0.62 & Smaragdia viridis & 1118 & 0.43 \\
\hline Nassarius reticulatus & 1377 & 0.38 & Pusillina inconspicua & 396 & 0.36 & Rissoa monodonta & 744 & 0.29 \\
\hline Pusillina inconspicua & 1133 & 0.31 & Nassarius reticulatus & 217 & 0.20 & Pusillina inconspicua & 737 & 0.29 \\
\hline Nassarius incrassatus & 803 & 0.22 & Anomia ephippium & 209 & 0.19 & Nassarius incrassatus & 639 & 0.25 \\
\hline Anomia ephippium & 583 & 0.16 & Bittium latreillii & 203 & 0.18 & Anomia ephippium & 374 & 0.14 \\
\hline Odostomia turrita & 372 & 0.10 & Nassarius incrassatus & 164 & 0.15 & Odostomia turrita & 325 & 0.13 \\
\hline Bittium latreillii & 368 & 0.10 & Modiolarca subpicta & 150 & 0.14 & Modiolarca subpicta & 177 & 0.07 \\
\hline Modiolarca subpicta & 327 & 0.09 & Polycera cf quadrilineata & 95 & 0.09 & Bittium latreillii & 165 & 0.06 \\
\hline Aplysia punctata & 185 & 0.05 & Musculus costulatus & 72 & 0.06 & Aplysia punctata & 144 & 0.06 \\
\hline Polycera cf quadrilineata & 138 & 0.04 & Marshallora adversa & 66 & 0.06 & Hiatella arctica & 67 & 0.03 \\
\hline Musculus costulatus & 123 & 0.03 & Mytilaster minimus & 48 & 0.04 & Mytilaster minimus & 57 & 0.02 \\
\hline Mytilaster minimus & 105 & 0.03 & Odostomia turrita & 47 & 0.04 & Rissoa violacea & 52 & 0.02 \\
\hline Hiatella arctica & 90 & 0.02 & Parvicardium scriptum & 42 & 0.04 & Musculus costulatus & 51 & 0.02 \\
\hline Species & $\% F$ & & Species & $\%$ & & Species & & $\% F$ \\
\hline Jujubinus striatus & 100.00 & & Jujubinus striatus & & & Jujubinus striatus & & 100.00 \\
\hline Nassarius pygmaeus & 100.00 & & Mitrella minor & & & Nassarius pygmaeus & & 100.00 \\
\hline Mitrella minor & 100.00 & & Nassarius pygmaeus & & & Mitrella minor & & 100.00 \\
\hline Calliostoma planatum & 100.00 & & Rissoa membranacea & & & Calliostoma planatum & & 100.00 \\
\hline Rissoa membranacea & 100.00 & & Calliostoma planatum & & & Rissoa membranacea & & 100.00 \\
\hline Bittium reticulatum & 100.00 & & Bittium reticulatum & & & Nassarius reticulatus & & 100.00 \\
\hline Smaragdia viridis & 100.00 & & Rissoa monodonta & & & Bittium reticulatum & & 100.00 \\
\hline Rissoa monodonta & 100.00 & & Smaragdia viridis & & & Smaragdia viridis & & 100.00 \\
\hline Nassarius incrassatus & 100.00 & & Anomia ephippium & & & Rissoa monodonta & & 100.00 \\
\hline Anomia ephippium & 100.00 & & Bittium latreillii & & & Nassarius incrassatus & & 100.00 \\
\hline Bittium latreillii & 100.00 & & Nassarius incrassatus & & & Anomia ephippium & & 100.00 \\
\hline Modiolarca subpicta & 92.00 & & Pusillina inconspicua & & & Odostomia turrita & & 100.00 \\
\hline Nassarius reticulatus & 84.00 & & Modiolarca subpicta & & & Modiolarca subpicta & & 100.00 \\
\hline Pusillina inconspicua & 84.00 & & Rissoa violacea & & & Bittium latreillii & & 100.00 \\
\hline Odostomia turrita & 84.00 & & Tricolia pullus & & & Pusillina inconspicua & & 83.33 \\
\hline Tricolia pullus & 80.00 & & Nassarius reticulatus & & & Tricolia pullus & & 83.33 \\
\hline Rissoa violacea & 80.00 & & Odostomia turrita & & & Calyptraea chinensis & & 83.33 \\
\hline Calyptraea chinensis & 72.00 & & Mytilaster minimus & & & Aplysia punctata & & 75.00 \\
\hline Mytilaster minimus & 68.00 & & Calyptraea chinensis & & & Rissoa violacea & & 75.00 \\
\hline Hiatella arctica & 60.00 & & Tricolia tenuis & & & Fusinus pulchellus & & 75.00 \\
\hline
\end{tabular}

$N$ total number of individuals collected

assemblages, the dominant species was by far the trochid Jujubinus striatus (\%D: $79.52 \%$ in diurnal and $60.28 \%$ in nocturnal). Due to the high dominance of this gastropod, there were nearly 113 spp. with dominance values under $1 \%$. The species Nassarius pygmaeus represented the second dominant species and increased about sixfold its 
dominance percentage at night $(24.94 \%)$ in relation with daytime $(4.01 \%)$. The columbellid Mitrella minor also increased its dominance in the nocturnal samples (8.51\%) compared to the diurnal ones (5.62\%), as well as the nassarids Nassarius reticulatus and $N$. incrassatus. Conversely, other species (e.g. Rissoa membranacea, Bittium reticulatum, Smaragdia viridis) decreased their dominance values in the nocturnal samples compared to the diurnal ones. In relation to the frequency of occurrence in the samples (Table 1), $11 \mathrm{spp}$. were found in all diurnal samples: J. striatus, $N$. pygmaeus, $M$. minor, Calliostoma planatum, R. membranacea, B. reticulatum, $S$. viridis, Rissoa monodonta, $N$. incrassatus, Anomia ephippium and Bittium latreillii. In the nocturnal assemblage, the previous species plus $N$. reticulatus, Odostomia turrita and Modiolarca subpicta were found in all nocturnal samples.

\section{Temporal dynamics}

The abundance or density of molluscs (individuals $\mathrm{m}^{-2}$ ) displayed a non-significant seasonal pattern (Fig. 2a), but the density was significantly higher in the nocturnal assemblage $\left(96.4 \pm 22.2\right.$ indiv. $\mathrm{m}^{-2} ; n=12$ nocturnal samples; Mean \pm standard deviation) compared to the diurnal one (37.8 \pm 9.9 indiv. $\mathrm{m}^{-2} ; n=13$ diurnal samples) (Two-factor ANOVA; Factor diel: $F=95.1, P<0.001$; Factor season: $F=2.4, P>0.05$; Interaction: $F=2.2, P>0.05)$. In
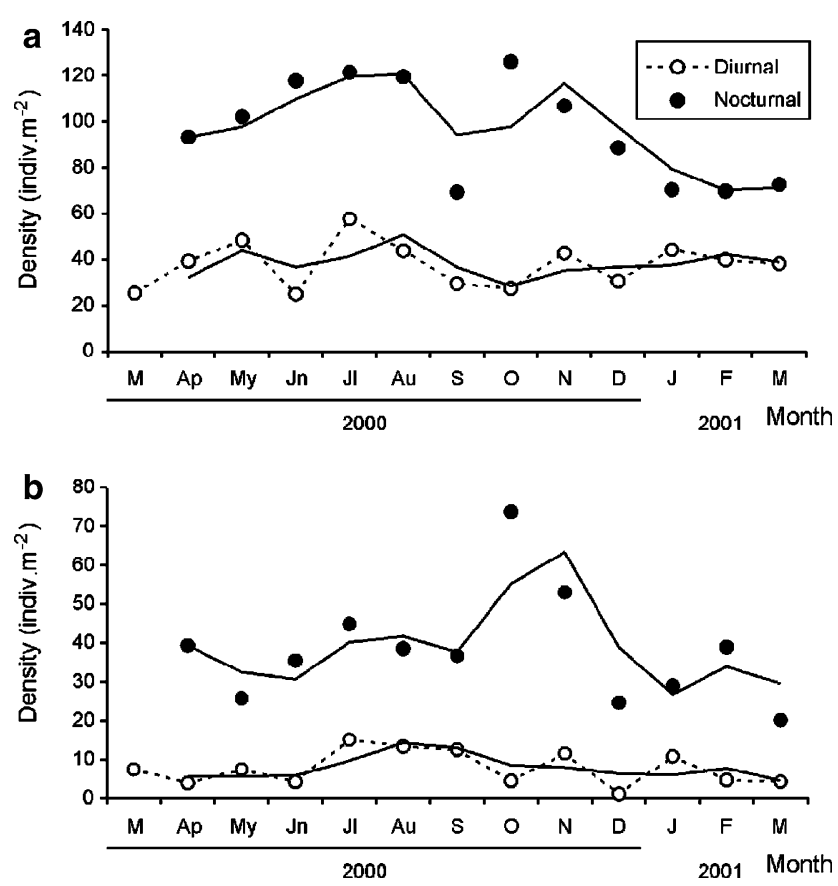

Fig. 2 Temporal dynamics of the density of molluscs (individuals $\mathrm{m}^{-2}$ ) for (a) the entire assemblage and (b) without the dominant species Jujubinus striatus during the day (empty symbols) and the night (solid symbols) in a Zostera marina bed (12-14 m depth). Solid line represents the mean value between contiguous months the diurnal assemblage, the density was maximal in spring and summer, when the recruitment peak of the top dominant species Jujubinus striatus occurs. Most dominant species (e.g. Mitrella minor, Rissoa spp, Smaragdia viridis) recruit also during spring-summer months. Nevertheless, the spring and summer values were not significantly higher than the autumn-winter values with or without $J$. striatus (in both cases One-factor ANOVA; $F=0.8, P>0.05$ ). On the contrary, the density of molluscs of the nocturnal assemblage was significantly high in spring-summer and autumn due to recruitment of J. striatus and Nassarius pygmaeus, respectively (One-factor ANOVA; $F=7.9$, $P<0.05)$.

The abundance values without the top dominant J. striatus were $70 \%$ lower (Fig. 2b), and displayed maximum values in summer for the diurnal assemblage and in autumn for the nocturnal one (recruitment of $N$. pygmaeus). In this case, the abundance of molluscs was only significantly higher in the nocturnal samples $\left(38.3 \pm 14.4\right.$ indiv. $\mathrm{m}^{-2}$; $n=12)$ than in the diurnal ones $\left(7.7 \pm 4.4\right.$ indiv. $\mathrm{m}^{-2}$; $n=13$ ) (Two-factor ANOVA; Factor diel: $F=60.3$, $P<0.001$; Factor season: $F=1.7, P>0.05$; Interaction: $F=1.3, P>0.05$ ).

The species richness displayed a similar and significant seasonal trend (Two-factor ANOVA; Factor season: $F=11.6, P<0.001)$ in the diurnal and nocturnal assemblages, with maximum values in summer (39-51 species. sample ${ }^{-1}$; Fig. 3a). The values registered in the nocturnal samples $\left(39.5 \pm 9.7\right.$ species. sample $\left.{ }^{-1} ; n=12\right)$ were also significantly higher than those obtained in the diurnal samples $\left(31.1 \pm 9.1\right.$ species. sample ${ }^{-1} ; n=13$ : Two-factor ANOVA; Factor diel: $F=10.6 ; P<0.005$ ).

The Shannon-Wiener diversity index followed a seasonal trend with maximum values in summer in the diurnal assemblage, coincident with the maximum of species richness (Fig. 3b). In the nocturnal assemblage, the values seemed more stable throughout the year although being maximal in summer and in winter months. The diversity values were significantly higher in the nocturnal assemblage $(1.6 \pm 0.2$ bits; $n=12)$ compared to the diurnal $(1.2 \pm 0.5$ bits; $n=13)$ and displayed a significant seasonal variation (Two-factor Anova: Factor diel: $F=7.0$, $P<0.05$; Factor season: $F=3.6, P<0.05$; Interaction: $F=1.6, P>0.05)$. The evenness displayed a similar seasonal trend, with significant differences between day and night and between seasons of the year (Fig. 3c) (Two-factor Anova: Factor diel: $F=5.0, P<0.05$; Factor season: $F=3.0, P<0.05$; Interaction: $F=1.7, P>0.05)$.

The heterogeneity between monthly samples was maximal in autumn for both the diurnal and nocturnal assemblages (Fig. 4a, b). The heterogeneity between diurnal and nocturnal samples in each month displayed high values in autumn and winter (Fig. 4c). 

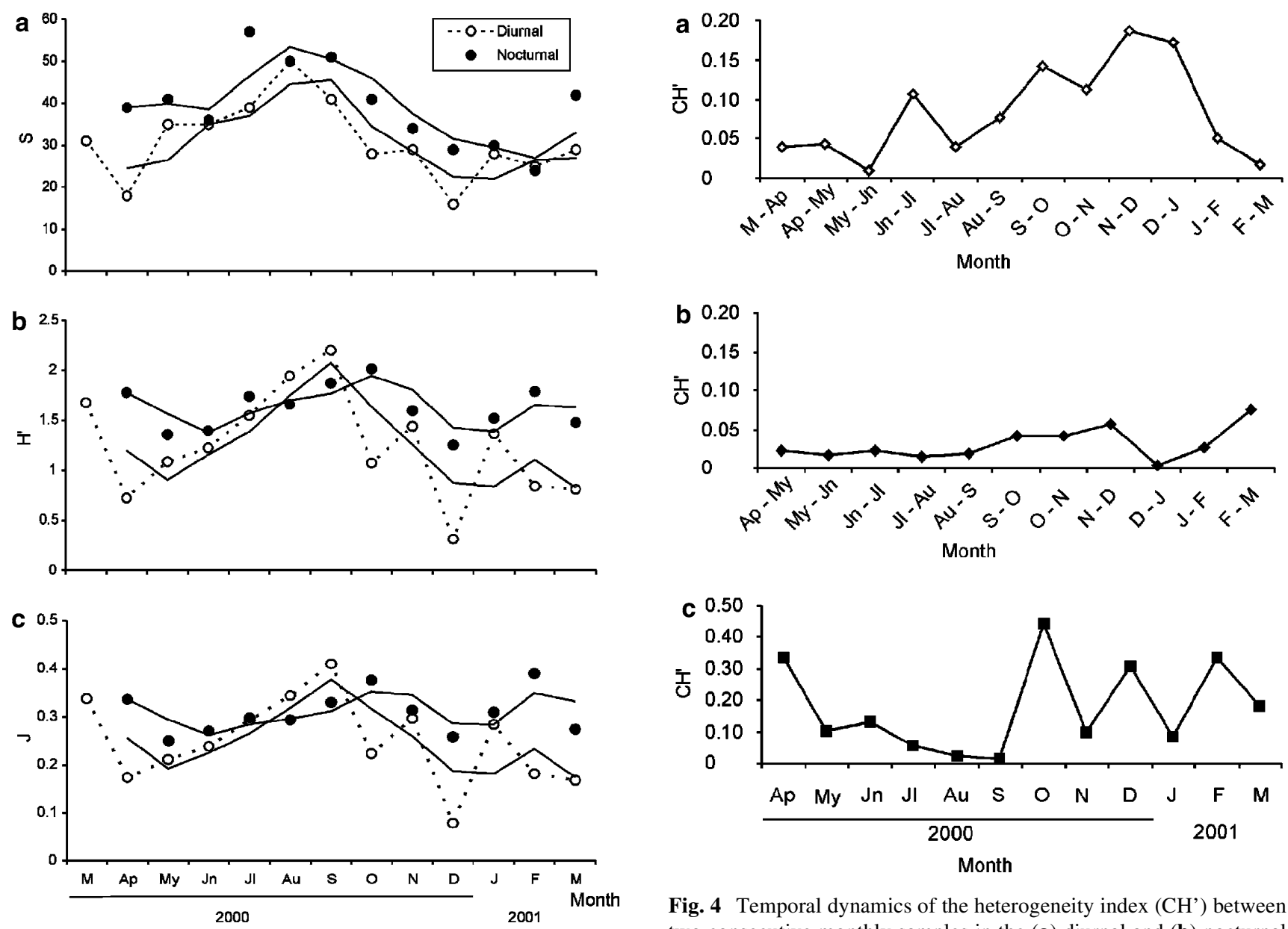

Fig. 3 Temporal dynamics of the molluscan (a) species richness (S), (b) Shannon-Wiener diversity index $\left(\mathrm{H}^{\prime}\right)$ and (c) evenness (J) during the day (empty symbols) and during the night (solid symbols) in a Zostera marina bed (12-14 $\mathrm{m}$ depth). Solid line represents the mean value between contiguous months

Differences between day and night: species abundance and trophic groups

Some dominant species displayed significantly higher abundances in the nocturnal samples in relation to the diurnal ones, such as the trochids $J$. striatus and $C$. planatum, the nassarids $N$. pygmaeus, $N$. reticulatus and $N$. incrassatus and the columbellid M. minor (in all cases one-factor ANOVA, $P<0.05$; Table 2). A similar result was obtained when performing the analysis for taxonomic group's abundance: nassarids, trochids and cephalopods showed significantly higher abundances (one-factor ANOVA, all $P<0.005$ ) in the nocturnal assemblage (Fig. 5a, b). Other dominant and frequent species did not show any significant differences between their diurnal and nocturnal abundances (e.g. the rissoids $R$. membranacea and $R$. monodonta or the cerithid $B$. reticulatum; Table 2). A similar result was obtained when performing the analysis for taxonomic groups: abundances of cerithids, conids and rissoids did not

Fig. 4 Temporal dynamics of the heterogeneity index ( $\left.\mathrm{CH}^{\prime}\right)$ between two consecutive monthly samples in the (a) diurnal and (b) nocturnal assemblages and (c) between the nocturnal and diurnal samples within each month for the molluscs associated with Zostera marina

vary significantly (one-factor ANOVA, all $P>0.05$ ) between day and night (Fig. 5).

The contribution of the different trophic groups in terms of number of species was similar in diurnal and nocturnal samples, except for carnivorous species (e.g. cephalopods, conids) that increased in the nocturnal samples (Fig. 6a). Conversely, the contribution of the different trophic groups in terms of abundance was larger for those herbivores feeding mainly on microalgae (e.g. J. striatus, Rissoa spp.) in both the diurnal and nocturnal samples (Fig. 6b). In the nocturnal samples there was an increase in the abundance of scavengers such as the nassarids compared to the diurnal samples.

\section{Cluster and ordination}

In both the cluster and MDS (based on Sorensen-Dice similarity index), groups of samples using qualitative data (presence/absence of species) reflect the seasonal sampling time (spring and summer samples vs. autumn and winter samples) rather than the diurnal versus nocturnal collection 
Table 2 Results of the one-factor ANOVA (diurnal vs. nocturnal) for testing differences in some dominant gastropods and bivalves monthly abundance in diurnal and nocturnal samples collected in a Zostera marina bed from March 2000 to 2001
$N$ number of samples collected, $d f$ degrees of freedom, SS Sums of squares, $M S$ Mean square, $F F$ ratios of mean square; $P$ Probability

\begin{tabular}{|c|c|c|c|c|c|c|}
\hline Source of variation & $N$ & $\mathrm{~d} f$ & SS & MS & $F$ & $P$ \\
\hline Jujubinus striatus & 25 & & & & & \\
\hline Diurnal versus Nocturnal & & 1 & $2.4210^{8}$ & $2.4210^{8}$ & 25.58 & $<0.001$ \\
\hline Error & & 23 & $2.1810^{8}$ & $9.4710^{6}$ & & \\
\hline Nassarius pygmaeus & 25 & & & & & \\
\hline Diurnal versus Nocturnal & & 1 & $1.5610^{8}$ & $1.5610^{8}$ & 62.78 & $<0.001$ \\
\hline Error & & 23 & $5.7210^{7}$ & $2.4910^{6}$ & & \\
\hline Mitrella minor & 25 & & & & & \\
\hline Diurnal versus Nocturnal & & 1 & $1.3810^{7}$ & $1.3810^{7}$ & 25.91 & $<0.001$ \\
\hline Error & & 23 & $1.0110^{7}$ & $4.3910^{5}$ & & \\
\hline Calliostoma planatum & 25 & & & & & \\
\hline Diurnal versus Nocturnal & & 1 & $4.1610^{5}$ & $4.1610^{5}$ & 15.35 & $<0.005$ \\
\hline Error & & 23 & $6.2410^{5}$ & $2.7110^{4}$ & & \\
\hline Rissoa membranacea & 25 & & & & & \\
\hline Diurnal versus Nocturnal & & 1 & 925.64 & 925.64 & 0.05 & $>0.05$ \\
\hline Error & & 23 & $4.3610^{5}$ & $1.9010^{4}$ & & \\
\hline Bittium reticulatum & 25 & & & & & \\
\hline Diurnal versus Nocturnal & & 1 & $2.7410^{4}$ & $2.7410^{4}$ & 0.62 & $>0.05$ \\
\hline Error & & 23 & $1.0210^{6}$ & $4.4310^{4}$ & & \\
\hline Smaragdia viridis & 25 & & & & & \\
\hline Diurnal versus Nocturnal & & 1 & $1.0510^{4}$ & $1.0510^{4}$ & 3.98 & 0.058 \\
\hline Error & & 23 & $6.0810^{4}$ & 2645.50 & & \\
\hline Rissoa monodonta & 25 & & & & & \\
\hline Diurnal versus Nocturnal & & 1 & 0.037 & 0.037 & 0.00 & $>0.05$ \\
\hline Error & & 23 & $5.6610^{4}$ & 2463.08 & & \\
\hline Nassarius reticulatus & 25 & & & & & \\
\hline Diurnal versus Nocturnal & & 1 & $3.9910^{4}$ & $3.9910^{4}$ & 11.17 & $<0.005$ \\
\hline Error & & 23 & $8.2210^{4}$ & 3572.84 & & \\
\hline Nassarius incrassatus & 25 & & & & & \\
\hline Diurnal versus Nocturnal & & 1 & $1.0310^{4}$ & $1.0310^{4}$ & 4.96 & $<0.05$ \\
\hline Error & & 23 & $4.7810^{4}$ & 2078.41 & & \\
\hline Anomia ephippium & 25 & & & & & \\
\hline Diurnal versus Nocturnal & & 1 & 1420.85 & 1420.85 & 1.92 & $>0.05$ \\
\hline Error & & 23 & $1.7010^{4}$ & 740.72 & & \\
\hline Musculus subpictus & 25 & & & & & \\
\hline Diurnal versus Nocturnal & & 1 & 64.36 & 64.36 & 0.17 & $>0.05$ \\
\hline Error & & 23 & 8633.48 & 375.37 & & \\
\hline Musculus costulatus & 25 & & & & & \\
\hline Diurnal versus Nocturnal & & 1 & 10.36 & 10.36 & 0.11 & $>0.05$ \\
\hline Error & & 23 & 2215.48 & 96.32 & & \\
\hline Mytilaster minimus & 25 & & & & & \\
\hline Diurnal versus Nocturnal & & 1 & 6.98 & 6.98 & 0.23 & $>0.05$ \\
\hline Error & & 23 & 703.02 & 30.57 & & \\
\hline Parvicardium scriptum & 25 & & & & & \\
\hline Diurnal versus Nocturnal & & 1 & 24.48 & 24.48 & 0.57 & $>0.05$ \\
\hline Error & & 23 & 990.56 & 43.07 & & \\
\hline Pectinidae & 25 & & & & & \\
\hline Diurnal versus Nocturnal & & 1 & 53.55 & 53.55 & 0.34 & $>0.05$ \\
\hline Error & & 23 & 3622.61 & 157.50 & & \\
\hline
\end{tabular}



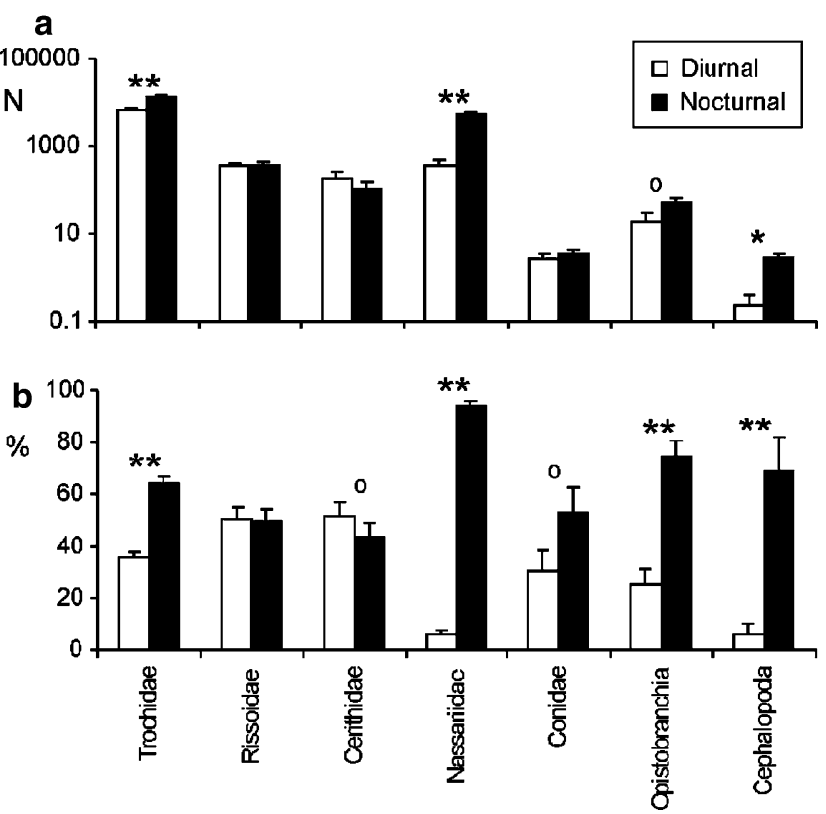

Fig. 5 Diurnal and nocturnal (a) abundance $(N)$ and (b) percentage (\%) of the main molluscan taxonomical groups in a Zostera marina bed. Percentage of each taxonomic group in relation to the mean number of individuals from that group found in the diurnal and in the nocturnal samples within the same month. Mean + standard deviation. Symbols represent the probability value obtained in one-factor ANOVA analysis (diurnal vs. nocturnal abundance); $* * P<0.001, * P<0.005$, ${ }^{o} P<0.1$
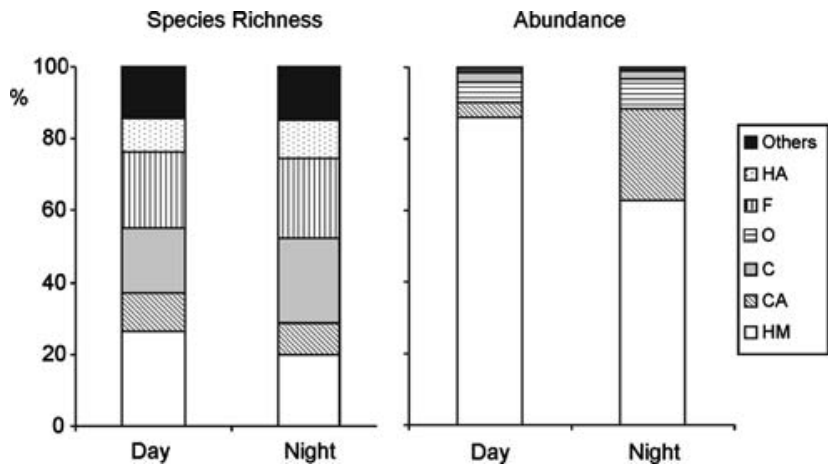

Fig. 6 Mean monthly percentage of main molluscan trophic groups in relation to (a) number of species and (b) abundance in the diurnal (Day) and in the nocturnal (Night) samples collected in a Zostera marina bed (12-14 m depth). $C$ Carnivores, $C A$ Scavengers, $F$ Filter feeders, $H A$ Macroalgae grazers, $H M$ Microalgae grazers, $O$ Egg feeders

(Fig. 7a, b). Based on ANOSIM analysis with two factors: (a) diurnal versus nocturnal months and (b) cold months season (autumn and winter months) versus warm months season (spring and summer months), samples from spring and summer had a significantly different composition in comparison with autumn and winter samples $\left(\mathrm{R}_{\mathrm{ANOSIM}}=0.40\right.$, $P<0.001)$. The diurnal and nocturnal samples also differed significantly in their composition but displayed a lower degree of variability compared to the seasonal changes
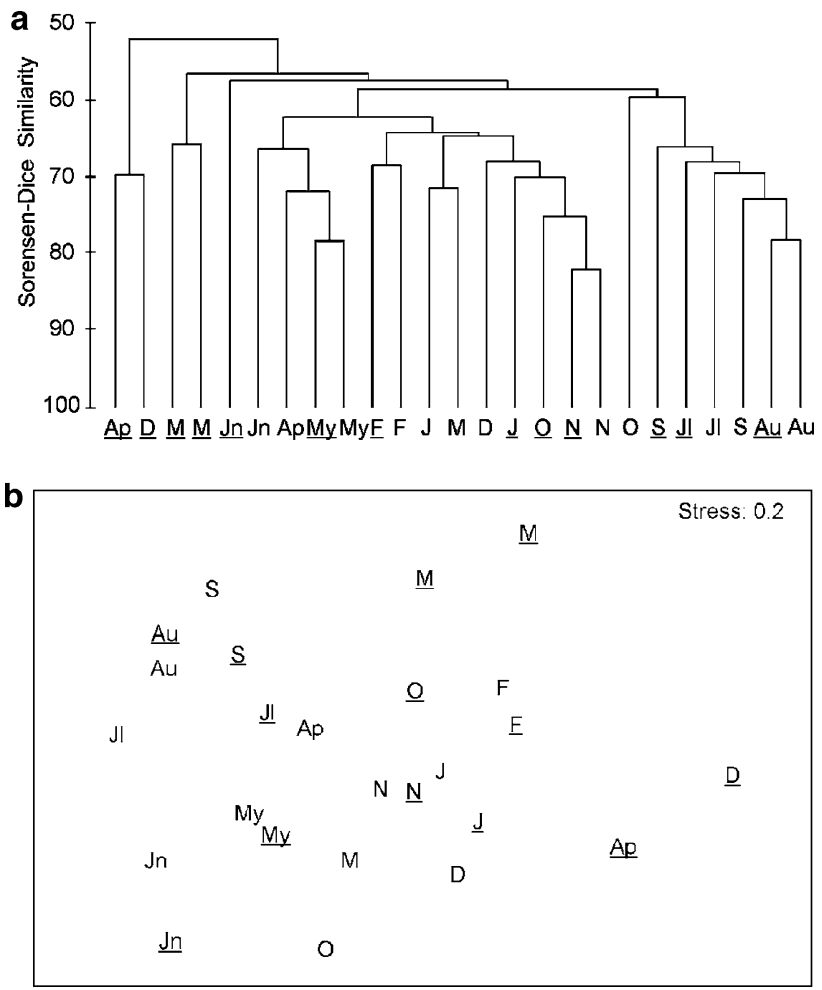

Fig. 7 (a) Cluster and (b) MDS based on qualitative (presence/absence) similarities (Sorensen-Dice index) among the molluscan assemblages found on the different monthly samples from March 2000 to 2001 in a Zostera marina bed (12-14 m depth). Underlined Diurnal samples. Not underlined Nocturnal samples

$\left(\mathrm{R}_{\text {ANOSIM }}=0.13, P<0.05\right)$. SIMPER analyses showed that the highest contribution for the diurnal versus nocturnal variation was given by the low frequency of occurrence of (1) Sepietta oweniana and Sepia officinalis, Fusinus pulchellus, Bela sp.1, Bolma rugosa, Aplysia spp. or Pleurobranchaea meckelii, during the day and (2) Ocinebrina aciculata, Tricolia tenuis or Euspira pulchella at night. The highest contribution for the seasonal variation was given by the low frequency of occurrence of (1) Musculus costulatus, Parvicardium scriptum, Mangelia unifasciata, Nassarius cuvieri, Tricolia tenuis, Marshallora adversa, Aplysia parvula or Pleurobranchaea meckelii, in cold months and (2) Williamia gussonii, Gregariella semigranata, Odostomia unidentata or Calyptraea chinensis, during warm months.

Taking into account the quantitative data (Bray-Curtis similarity index), samples form groups related to both diurnal versus nocturnal collection and with seasons (spring-summer months versus autumn-winter: Fig. 8a, b). ANOSIM analysis, performed with the same factors as above, indicated significant differences when testing both the composition and structure of the assemblage between day and night $\left(\mathrm{R}_{\mathrm{ANOSIM}}=0.39, P<0.005\right)$ and between warm (spring-summer) and cold (autumn-winter) periods $\left(\mathrm{R}_{\text {ANOSIM }}=0.34, P<0.005\right)$. SIMPER analyses showed 


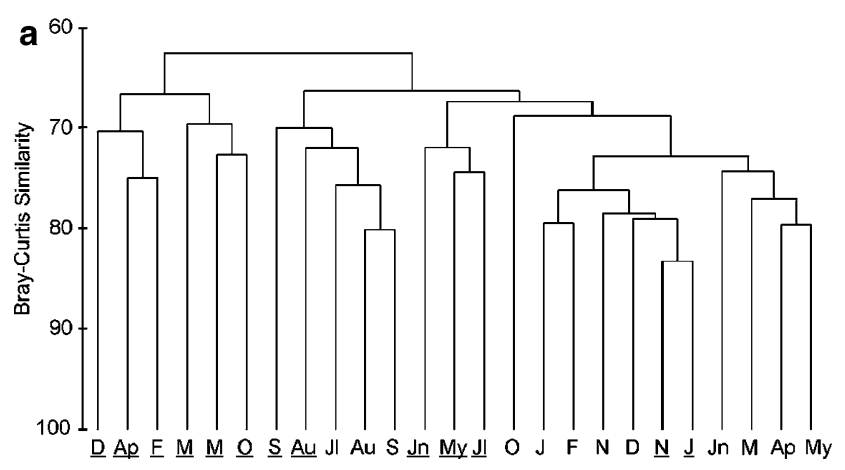

b

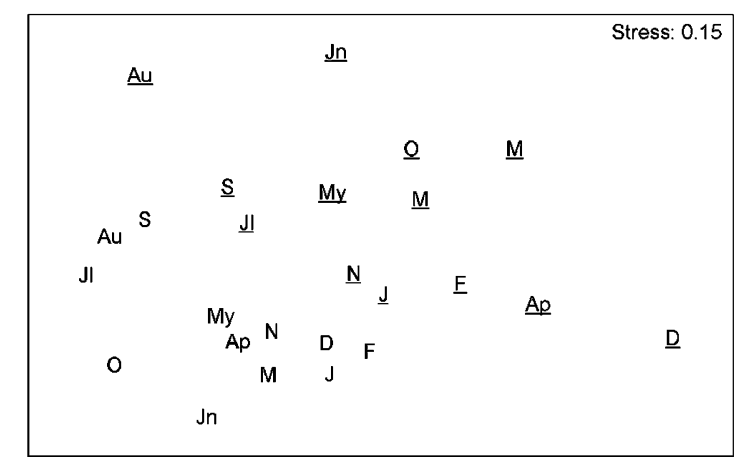

Fig. 8 (a) Cluster and (b) MDS based on quantitative (fourth root transformed data) similarities (Bray-Curtis index) among the molluscan assemblages found on the different monthly samples from March 2000 to 2001 in a Zostera marina bed (12-14 m depth). Underlined Diurnal samples. Not underlined Nocturnal samples

that the highest contribution for the diurnal versus nocturnal variation was given by (1) the lowest abundance of $N$. pygmaeus, M. minor, $N$. reticulatus, J. striatus, $P$. inconspicua, Odostomia turrita or Aplysia punctata during the day and (2) by mainly the lowest abundance of Bittium reticulatum during the night. The highest contribution for the seasonal variation was given by (1) Musculus costulatus, Modiolarca subpicta, $P$. inconspicua, M. minor, B. reticulatum, $N$. reticulatus, J. striatus and A. punctata (low abundance in autumn and winter) and (2) as $N$. pygmaeus and $O$. turrita (low abundance during spring and summer).

\section{Discussion}

Composition and structure

The size of sampling area represents an important aspect on studies on the faunistic composition of certain types of habitats. In this study, with $222 \mathrm{~m}^{2}$ for each sample, the area is much larger than in previous studies on molluscan taxocoenoses associated with Zostera marina beds (normally less than $1 \mathrm{~m}^{2}$ per sample: Jacobs and Huisman 1982; Jacobs et al. 1983; Currás et al. 1993; Boström and Bonsdorff 1997, 2000; Çinar et al. 1998; Frost et al. 1999; Hily and
Bouteille 1999; Sfriso et al. 2001). This area was established taking into account the minimum area needed to collect mobile organisms (e.g. crustaceans, fish), currently under study. The sampling area using the Agassiz trawl is systematically much larger than that using box-cores or quadrats, increasing the likelihood of collecting rare species (e.g. Conidae, Opisthobranchs, Cephalopods). Conversely, some infaunal species are not collected with this sampling methodology (e.g. Lucinidae, Tellinidae: Rueda and Salas, personal observation). One of the advantages of the gear is that it causes a lower disturbance to the Z. marina plants since shoots are not directly collected.

The composition and structure of the molluscan assemblage associated with Zostera marina beds at 12-14 m depth in Cañuelo Bay is similar to that found in a previous study using the same sampling methodology in a patchy $Z$. marina bed located within the MPA at Cantarrijan Bay (Arroyo et al. 2006; Fig. 1). In the latter site, only diurnal samples were collected, resulting in a lower number of species found (80 spp). Moreover, the abundance of species associated with the leaf stratum such as J. striatus, S. viridis or Rissoa spp. was significantly lower in Cantarrijan Bay (fragmented eelgrass bed) as compared to Cañuelo Bay (non-fragmented bed). The lower number and abundance of species could be related to the fragmentation level of the eelgrass beds, as found in other studies on benthic communities of shallower Z. marina beds (Webster et al. 1998; Frost et al. 1999; Attrill et al. 2000).

Molluscs in seagrass beds are an important component of the fauna, when considering their species richness and number of individuals (Hemminga and Duarte 2000; Williams and Heck 2001). As a comparison, the fish assemblage from the eelgrass bed of Cañuelo Bay is composed of a lower number of species (73 species; 46 spp. in diurnal and 64 spp. in nocturnal samples) and density (2-3 individuals. $\mathrm{m}^{-2}$; Reina Hervas et al. 2006). In some Zostera marina beds from North America, molluscs and polychaetes are the most diverse and abundant groups of the macrofauna, when compared to crustaceans, echinoderms and fishes (Mattila et al. 1999). In other eelgrass beds, some groups (e.g. crustaceans) may display higher number of species than molluscs, but not higher densities (Marsh 1973; Thayer et al. 1975; Nakaoka et al. 2001). In other types of seagrass beds (e.g. Posidonia oceanica, Cymodocea nodosa, Zostera noltii), molluscs are also a dominant group, displaying normally higher densities than other abundant groups such as polychaetes (Sfriso et al. 2001) or crustaceans (e.g. amphipods: Sánchez-Jerez et al. 1999).

Intra-annual variation

The abundance and diversity of molluscs showed a seasonal trend with maximum values in spring- summer in 
the eelgrass bed at Cañuelo Bay. This trend is similar to that observed in the smaller and more-fragmented eelgrass bed located in the adjacent Cantarrijan Bay at 14-16 m depth (Arroyo et al. 2006). Similar trends have been registered in other eelgrass beds along the Atlantic (Jacobs et al. 1983; Currás et al. 1993; Quintas 2005) and Mediterranean coasts of Europe (Sfriso et al. 2001; infauna: Çinar et al. 1998), as well as in other locations of the northern Hemisphere (Nakaoka et al. 2001; Bologna 2006). This trend has also been found for the molluscs associated with other softbottom seagrasses in Europe (Zostera noltii: Jacobs et al. 1983; Currás and Mora 1992, Cymodocea nodosa: Scipione et al. 1996; Chemello et al. 1997) or with seaweed beds (Caulerpa prolifera: Rueda and Salas 2003a) and is different to findings in Posidonia oceanica beds, in which maximal values may occur in summer-autumn (Russo et al. 1984; Hergueta 1996).

In the studied eelgrass bed, the temporal variation in abundance is related to (1) recruitment of some dominant epifaunal species mainly during spring and summer (e.g. $J$. striatus, M. minor, Rissoa spp.) and (2) increase of mortality during autumn and winter of some epifaunal species associated with the leaf stratum (e.g. S. viridis or Rissoa spp.), probably due to the decline of the $Z$. marina leaf area index during this period of the year (Guidetti 2000; Rueda et al. 2008). In other studies on the temporal dynamics of molluscan taxocoenoses in southern Spain, the seasonal trend of the molluscan abundance was mainly related to the recruitment events of the dominant species (Rueda et al. 2001; Rueda and Salas 2003a, b). The presence of seasonal trends in the abundance and evenness of the species may promote seasonal values of the diversity index because the diversity index of Shannon-Wiener depends on the species richness and the evenness (abundance of species) (Krebs 1989). In this context, the decrease in the diversity values during spring are related to the recruitment peak of J. striatus, as registered in eelgrass beds from northern Spain (Quintas 2005) or in C. prolifera beds (Rueda and Salas 2003a) and during autumn due to the recruitment of Nassarius pygmaeus. On the contrary, maximum values of the diversity index during summer are related to maximum values of species richness.

The species richness in the eelgrass bed from Cañuelo Bay is maximal in summer (up to $55 \mathrm{spp}$ ) and minimal in winter (down to 20-30 spp) (Fig. 3). In eelgrass beds located in the Atlantic European coasts, the species richness is much lower with maximal values in summer up to 25 spp. and minimal in winter down to $4 \mathrm{spp}$ (Currás et al. 1993; Quintas 2005; Fredriksen et al. 2005). In estuarine areas (Oostershelde, The Netherlands), the species richness of molluscs remains very stable along the year, considering that these molluscan taxocoenosis are oligospecific with only 5-6 species present (Jacobs et al. 1983). In Mediterra- nean eelgrass beds (e.g. Venice Lagoon), the species richness of molluscs is also lower (22 spp.) than that of Cañuelo Bay, but maximal values also occur in spring and summer (Sfriso et al. 2001). One exception is the trend observed in an eelgrass bed located on the Turkish Mediterranean coasts, in which species richness of molluscs was maximal in autumn and winter, with only 3-5 infaunal species (Çinar et al. 1998). Nevertheless, no epifaunal species were collected in this eelgrass bed, due to unknown local circumstances or a sampling bias. Similar trends have been registered in other eelgrass beds of the Atlantic and Pacific coasts (Marsh 1976; Nakaoka et al. 2001) as well as in beds of other seagrass species from soft bottoms (e.g. Zostera noltii: Jacobs et al. 1983, Cymodocea nodosa: Scipione et al. 1996; Terlizzi and Russo 1997). On the contrary, the species richness of molluscs in Posidonia oceanica beds seems to be maximal in autumn and winter (macrofauna: Gambi et al. 1992; molluscan fauna: Hergueta 1996; Russo et al. 1991; Scipione et al. 1996). This contradiction could be explained by the architecture of the Posidonia bed, with the presence of a perennial hard substratum conformed by the rhizome.

The seasonal pattern of the species richness is similar to that of variables linked with the leaf stratum (e.g. shoot length, density) of $Z$. marina, which is maximal in spring and summer (Rueda et al. 2008) as found in other eelgrass beds (European Atlantic: Jacobs et al. 1983; Boström et al. 2003; Mediterranean: Guidetti 2000; United States: Thayer et al. 1975, 1977; Nelson and Waaland 1997; Japan: Toyohara et al. 1999; Nakaoka et al. 2001). The increase of the leaf stratum during spring and summer, and its overgrowth with epiphytic algae, promotes the presence of species from adjacent habitats such as seaweeds (e.g. Pusillina philippi, Pollia dorbignyi, Mytilaster minimus, Chlamys flexuosa), including those species that use the eelgrass bed as a foraging and spawning ground (e.g. Conidae, Aplysia spp.).

\section{Diel variation}

There are few studies regarding the variation of the molluscan taxocoenoses between day and night in seagrass beds (Templado 1982; Mattila et al. 1999; Sánchez-Jerez et al. 1999) or on unvegetated bottoms (Le Loeuff and Intès 1999). Some of these works concluded that diel changes in mollusc abundance were lower than those in other taxonomic groups (e.g. decapods, amphipods) (Le Loeuff and Intès 1999; Sánchez-Jerez et al. 1999). Most studies on diel variation have focussed on organisms with a larger mobility than most molluscs (e.g. fish), in which abundance changes were related to the use of different types of habitats during day or night (Griffiths 2001; Guest et al. 2003). The exceptions are the cephalopods, which were more abundant in nocturnal samples, as reported in a previous study for 
Zostera capricorni beds (Guest et al. 2003). Since these carnivorous molluscs can move between different habitat types or bury in the sediment within the eelgrass bed (Summers 1983), their type of movements is similar as the one exhibited by fish which may move at night time to forage (Griffiths 2001; Guest et al. 2003). On the other hand, Templado (1982) found that some gastropod species strictly occurred in the leaf stratum at nighttime in a Posidonia oceanica bed. In this case, movement is mainly vertical from the base/rhizomes to the canopy; nevertheless cases of movement from sediment to seagrasses have also been documented (Klumpp et al. 1992).

The diel variation of the molluscan taxocoenosis affects both its abundance and species richness values and is related to the vertical movement of some species along the shoots or from the sediment to the shoots (Molluscs: Templado 1982; Crustaceans: Sánchez-Jerez et al. 1999). This dynamics is different from the seasonal variation in which there are real changes in the abundance of individuals of a certain species related to its life cycle (e.g. recruitments). Considering that, the nocturnal samples reflect better the molluscan assemblage associated with $Z$. marina, with a higher stability along the year when compared with the diurnal samples.

The higher nocturnal abundance of the trochid Jujubinus striatus may be related to its movement towards the apical part of the shoots where epiphytes are very abundant (Mazzella et al. 1992; Hily et al. 2004). This is coincident with the observations of Templado (1982) who found higher densities of the trochids $C$. laugieri (similar to $C$. planatum), J. exasperatus and J. striatus at nighttime. Nocturnal migrations along the seagrass shoots have also been observed in other trochids, e.g Thalotia conica (Nielsen and Lethbridge 1989). Hickman (2005) observed that this gastropod occurred in the base of blades of Posidonia australis at daytime, whereas the trochids Phasianotrochus irisodontes and Prothalotia lehmanni were located near the tips. Vertical movements for feeding (Edgar and Robertson 1992) or spawning (Hickman and Porter 2007) have also been documented in scissurellid gastropods of macroalgae and seagrass beds.

The nassarids (N. pygmaeus, $N$. reticulatus and $N$. incrassatus) also displayed higher abundances in the nocturnal samples. Their vertical movements are reflected by the presence of high numbers of egg capsules at different heights along the eelgrass shoots, especially in the first 10 $\mathrm{cm}$ from the shoot base (Rueda 2007). Thus, these species are not permanently confined to the sediment stratum, as documented for other gastropods by Klumpp et al. (1992). The mechanisms controlling the vertical movements in those trochids or nassarids of the studied Z. marina bed are still unknown. An increase of nocturnal activity has been related to the presence of photoreceptors in the ocular area in opistobranchs (Jacklet 1969; Jing and Gillette 1995; Roberts and Xie 1996; Newcomb et al. 2004), and probably the diel behaviour is also related to feeding strategies as found in seagrass dominant organisms (Klumpp et al. 1992).

Day and night variability is not a common feature of all molluscan species of the studied Z. marina bed, because other herbivorous species, such as Rissoa membranacea, $R$. monodonta and B. reticulatum, did not show any diel differences in their abundances. Templado (1982) also observed a similar trend in the rissoids $R$. violace $a$ and $R$. ventricosa. In this case, these small species (shell height $<10 \mathrm{~mm}$ ) are generally located in the leaf stratum, where their food source (e.g. benthic diatoms) is highly available and may not move to the sediment during day or nighttime. The absence of diel vertical movements may be the case for a high number of gastropod species; nevertheless this type of behaviour seems to be more commonplace in microgastropods compared to macrogastropods (Hickman 2005).

\section{Conclusions}

The molluscan assemblage associated with deep subtidal $Z$. marina beds from southern Spain is more diverse than those of other eelgrass beds in Europe. Nevertheless, the seasonal dynamics of the ecological indices is very similar to that previously found in other shallower eelgrass beds of the northern Hemisphere and in other soft-bottom seagrasses of Europe. The temporal variation appears to be related to the phenology of the plant and to the biology of the mollusc species, such as recruitment. Variation between day and night is mainly due to vertical movements of some species (e.g. J. striatus, $N$. pygmaeus) along the shoots or from the sediment to the plant. Horizontal movements, incursions into the meadow from neighbouring habitats, are mainly displayed by cephalopods at nighttime. As a consequence, values of abundance and species richness are generally higher in the nocturnal samples than in the diurnal ones. Therefore, nocturnal sampling represents a better approach for increasing the knowledge on the molluscan fauna living on Zostera marina beds, and probably on other seagrasses too.

Acknowledgments We are grateful to Serge Gofas from the University of Malaga (UMA-Spain) for his supportive help in the collection of samples, revision of molluscan species and comments made during the preparation of this manuscript. We are also in debt to Enrique García-Raso, María Eugenia Manjón-Cabeza, Jose A. Reina Hervas, Vanesa Cobos, Vanessa Díaz and María Jose Martín, from UMA, for their help in the collection and processing of samples. Antonio Pulido (Director of the MPA, Junta de Andalucía) is thanked for sampling permissions and Michele K. Nishiguchi from New Mexico State University (USA) for identification of cephalopod specimens. We 
would like to thank the two anonymous reviewers of this journal for their contribution. The Spanish M.E.C. has financially supported this study with DGICYT funds, Project PB97-1116 "Estudio de la macrofauna de los fondos de fanerógamas marinas, Zostera y Cymodocea, del Sur de España”.

\section{References}

Arroyo MC, Salas C, Rueda JL, Gofas S (2006) Temporal changes of mollusc populations from a Zostera marina bed in southern Spain (Alboran Sea), with biogeographic considerations. Mar Ecol 27:417-430

Attrill MJ, Strong JA, Rowden AA (2000) Are macroinvertebrate communities influenced by seagrass structural complexity? Ecography 23:114-121

Bañares-España E, Báez JC, Casado MD, Díaz de Rada C, FloresMoya A, Rey J (2002) Distribución y estado de las fanerógamas marinas en el Paraje natural Acantilados de Maro-Cerro Gordo (Málaga-Granada). In: García-Gómez JC, Finlayson C (eds) Libro de Resúmenes, XII Simposio Ibérico del Bentos Marino. Algeciras, Spain, pp 30-31

Bologna PAX (2006) Assessing within-habitat variability in plant demography, faunal density, and secondary production in an eelgrass (Zostera marina L.) bed. J Exp Mar Biol Ecol 329:122-134

Boström C, Bonsdorff E (1997) Community structure and spatial variation of benthic invertebrates associated with Zostera marina $(\mathrm{L}$. beds in the northern Baltic Sea. J Sea Res 37:153-166

Boström C, Bonsdorff E (2000) Zoobenthic community establishment and habitat complexity-the importance of seagrass shoot-density, morphology and physical disturbance for faunal recruitment. Mar Ecol Prog Ser 205:123-138

Boström C, Baden SP, Krause-Jensen D (2003) The seagrasses of Scandinavia and the Baltic Sea. In: Green EP, Short FT (eds) World atlas of seagrasses, University of California Press, California, pp 27-37

Bray RJ, Curtis JT (1957) An ordination of the uplands forest communities of southern Wisconsin. Ecol Monogr 27:325-347

Chemello R, Scotti G, Riggio S (1997) The molluscan assemblage of the leaf stratum in a Cymodocea nodosa bed of a marine coastal lagoon. Boll Malacol 33:69-76

Clarke KR (1993) Non-parametric multivariate analyses of changes in community structure. Aust J Ecol 18:117-143

Clarke KR, Green RH (1988) Statistical design and analysis for a "biological effects" study. Mar Ecol Prog Ser 46:213-226

Clarke KR, Warwick RM (1994) Change in marine communities: an approach to statistical analysis and interpretation. Plymouth Marine Laboratory, Plymouth

Currás A, Mora J (1992) Variación temporal de la fauna bentónica en un fondo de Zostera noltii situado en la ría del Eo (NO de España). Bol Inst Esp Oceanogr 8:299-309

Currás A, Sánchez-Mata A, Mora J (1993) Estudio comparativo de la macrofauna bentonica de un fondo de Zostera marina y un fondo arenoso libre de cubierta vegetal. Cah Biol Mar 35:91-112

Çinar ME, Ergen Z, Ozturk B, Kirkim F (1998) Seasonal analysis of zoobenthos associated with a Zostera marina $\mathrm{L}$. bed in Gulbahce Bay (Aegean Sea, Turkey). P S Z N I: Mar Ecol 19:147-162

Duarte CM (2002) The future of seagrass meadows. Environ Conserv 29:192-206

Edgar GJ, Robertson AI (1992) The influence of seagrass structure on the distribution and abundance of mobile epifauna: pattern and process in a Western Australia Amphibolis bed. J Exp Mar Biol Ecol 160:13-31

Fredriksen S, Hartvig C, Sæthre BA (2005) Species richness in macroalgae and macrofauna assemblages on Fucus serratus L. (Phaeo- phyceae) and Zostera marina L. (Angiospermae) in Skagerrak, Norway. Mar Biol Res 1:2-19

Frost MT, Rowden AA, Attrill MJ (1999) Effect of habitat fragmentation on the macroinvertebrate infaunal communities associated with the seagrass Zostera marina L. Aquat Conserv Mar Freshw Ecosyst 9:255-263

Gambi MC, Lorenti M, Russo GF, Scipione MB, Zupo V (1992) Depth and seasonal distribution of some groups of the vagile fauna of the Posidonia oceanica leaf stratum: Structural and trophic analyses. P S Z N I: Mar Ecol 13:17-39

García-Raso JE, Salas C, Gofas S, Barrajón A, García-Muñoz JE (2004) Las praderas de Zostera marina. La comunidad de Zostera marina: Flora y Fauna. In: Luque ÁA, Templado J (eds) Praderas y bosques marinos de Andalucía. Consejería de Medio Ambiente, Junta de Andalucía, Sevilla, pp 162-172

García-Raso JE, Martín MJ, Díaz V, Cobos V, Manjón-Cabeza ME (2006) Diel and seasonal changes in the structure of a Decapod (Crustacea: Decapoda) community of Cymodocea nodosa from Southeastern Spain (West Mediterranean Sea). Hydrobiologia 557:59-68

Glémarec M (1969) Les peuplements benthiques du plateau continental Nord-Gascogne. Dissertation, University of Paris, France, unpublished

Gray CA, Chick RC, McElligott DJ (1998) Diel changes in assemblages of fishes associated with shallow seagrass and bare sand. Estuar Coast Shelf Sci 46:849-859

Green EP, Short FT (2003) World atlas of seagrasses. University of California Press, California, p 298

Griffiths SP (2001) Diel variation in the seagrass ichthyofaunas of three intermittently open estuaries in south-eastern Australia: implications for improving fish diversity assessments. Fish Manag Ecol 8:123-140

Guest MA, Connolly RM, Loneragan NR (2003) Seine nets and beam trawls compared by day and night for sampling fish and crustaceans in shallow seagrass habitat. Fish Res 64:185-196

Guidetti P (2000) Temporal dynamics of Zostera marina L. off the Lagoon of Grado (Northern Adriatic Sea, Italy). Bot Mar 43:541546

Guidetti P, Lorenti M, Buia MC, Mazzella L (2002) Temporal dynamics and biomass partitioning in three Adriatic seagrass species: Posidonia oceanica, Cymodocea nodosa, Zostera marina. P S Z N I Mar Ecol 23:51-67

Hemminga MA, Duarte CM (2000) Seagrass ecology. Cambridge University Press, Cambridge, p 298

Hergueta E (1996) Estudio de las taxocenosis malacológicas asociadas a concrecionamientos de Mesophyllum lichenoides (Ellis) Lemoine y a una pradera de Posidonia oceanica (Linnaeus) Delile del litoral almeriense. Dissertation, University of Málaga, Spain, unpublished

Hickman CS (2005) Seagrass fauna of the temperate southern coast of Australia I: the cantharadine trochid gastropods. In: Wells FE, Walker DI, Kendrick GA (eds) The Marine Flora and Fauna of Esperance, Western Australia, Western Australia Museum, Perth, pp 199-220

Hickman CS, Porter SS (2007) Nocturnal swimming, aggregation at light traps, and mass spawning of scissurellid gastropods (Mollusca: Vetigastropoda). Invertebr Biol 126:10-17

Hily C, Bouteille M (1999) Modifications of the specific diversity and feeding guilds in an intertidal sediment colonized by an eelgrass meadow (Zostera marina) (Brittany, France). C R Acad Sci III 322:1121-1131

Hily C, Connan S, Raffin C, Willey-Echeverria S (2004) In vitro experimental assessment of the grazing pressure of two gastropods on Zostera marina L. epiphytic algae. Aquat Bot 78:183-195

Irlandi EA (1994) Large- and small-scale effects of habitat structure on rates of predation: how percent coverage of seagrasses affects 
rates of predation and siphon nipping on an infaunal bivalve. Oecologia 98:176-183

Irlandi EA (1997) Seagrass patch size and survivorship of an infaunal bivalve. Oikos 78:511-518

Jacklet JW (1969) Circadian rhythm of optic nerve impulses recorded in darkness from isolated eye of Aplysia. Science 164:562-563

Jacobs RPWM, Huisman WHT (1982) Macrobenthos of some Zostera beds in the vicinity of Roscoff (France) with special reference to relations with community structure and environmental factors. Proc Kon Ned Akad Wet 85:335-356

Jacobs RPWM, Hegger HH, Ras-Willems A (1983) Seasonal variations in the structure of a Zostera community on tidal flats in the SW Netherlands, with special reference to the benthic fauna. Proc Kon Ned Akad Wet 86:347-375

Jing J, Gillette R (1995) Neuronal elements that mediate escape swimming and suppress feeding behaviour in the predatory sea slug Pleurobranchaea. J Neurophysiol 74:1900-1910

Kharlamenko VI, Kiyashko SI, Imbs AB, Vyshkvartzev DI (2001) Identification of food sources of invertebrates from the seagrass Zostera marina community using carbon and sulphur stable isotope ratio and fatty acid analyses. Mar Ecol Prog Ser 220:103-117

Klumpp DW, Salita-Espinosa JS, Fortes MD (1992) The role of epiphytic periphyton and macro-invertebrate grazers in the trophic flux of a tropical seagrasss community. Aquat Bot 43:327-349

Krebs CJ (1989) Ecological methodology. Harper and Row, New York, $\mathrm{p} 654$

Laugier T, Rigollet V, de Casabianca ML (1999) Seasonal dynamics in mixed eelgrass beds Zostera marina $\mathrm{L}$. and Z. noltii Hornem. in a Mediterranean coastal lagoon (Thau lagoon, France). Aquat Bot 63:51-69

Ledoyer M (1966) Écologie de la faune vagile des biotopes méditerranéens accessibles en scaphandre autonome. II. Donnés analytiques sur les herbiers de phanérogames (1). Rec Trav St Mar 41:135-165

Le Loeuff P, Intès A (1999) Macrobenthic communities on the continental shelf of Côte-d'Ivoire. Seasonal and diel cycles in relation to hydroclimate. Oceanol Acta 22:529-550

Marbà N, Cebrián J, Enríquez S, Duarte CM (1996) Growth patterns of Western Mediterranean seagrasses: species-specific responses to seasonal forcing. Mar Ecol Progr Ser 133:203-215

Margalef R (1956) Información y diversidad específica en las taxocenosis de organismos. Invest Pesq 3:99-106

Mars P (1966) Recherches sur quelques étangs du litoral méditerranéen francais et sur leurs faunes malacologiques. Vie et Milieu suppl 20:1-359

Marsh GA (1973) The Zostera epifaunal community in the York River, Virginia. Chesap Sci 14:87-97

Marsh GA (1976) Ecology of the gastropod epifauna of eelgrass in a Virginia estuary. Chesap Sci 17:182-187

Mattila J, Chaplin G, Eilers MR, Heck KL, O’Neal JP, Valentine JF (1999) Spatial and diurnal distribution of invertebrate and fish fauna of a Zostera marina bed and nearby unvegetated sediments in Damariscotta River, Maine (USA). J Sea Res 41:321-332

Mazzella L, Buia MC, Gambi MC, Lorenti M, Russo GF, Scipione MB, Zupo V (1992) Plant-animal trophic relationships in the Posidonia oceanica ecosystem of the Mediterranean Sea: a review. In: John DM, Hawkins SJ, Price JH (eds) Plant-animal interactions in the marine benthos, systematics association special, vol 46. Clarendon Press, Oxford, pp 165-187

Mazzella L, Buia MC, Gambi MC, Lorenti M, Russo GF, Scipione MB, Zupo V (1995) A review on the trophic organization in the Posidonia oceanica ecosystem. In: Cinelli F, Fresi E, Lorenzi C, Mucedola A (eds) La Posidonia oceanica: Un contributo per la salvaguardia del principale ecositema marino del Mediterraneo. Rivista Marítima, Fusa Editrice, Roma, pp 40-47
Nakaoka M, Toyohara T, Matsumasa M (2001) Seasonal and betweensubstrate variation in mobile epifaunal community in a multispecific seagrass bed of Otsuchi Bay, Japan. P S Z N I: Mar Ecol 22:379-395

Nelson TA, Waaland JR (1997) Seasonality of eelgrass, epiphyte and grazer biomass and productivity in subtidal eelgrass meadows subjected to moderate tidal amplitude. Aquat Bot 56:51-74

Newcomb JM, Lawrence KA, Watson III WH (2004) The influence of light on locomotion in the gastropod Melibe leonina. Mar Freshw Behav Physiol 37:253-269

Niell X, Rucabado J (1981) Structural heterogeneity in benthic algal communities. Proceedings of the 8th International Seaweeds symposium, pp 425-433

Nielsen J, Lethbridge R (1989) Feeding and epiphyte food resources of gastropods living on the leaves of the seagrass Amphibolis griffthii in southwestern Australia. J Malacol Soc Aust 10:47-58

Petrakis G, MacLennan DN, Newton AW (2001) Day-night and depth effects on catch rates during trawl surveys in the North Sea. ICES J Mar Sci 58:50-60

Pielou EC (1969) An introduction to mathematical ecology. Wiley, New York, p 285

Quintas P (2005) Distribución espacial y temporal de los moluscos y anélidos poliquetos asociados a las praderas de Zostera marina $\mathrm{L}$. y Zostera noltii Hornem. en la ensenada de O Grove (Galicia, España). Dissertation, University of Vigo, Spain, unpublished

Reina Hervas JA, Rueda JL, García Muñoz JE, García Raso JE (2006) Estructura de una población íctica asociada a una pradera de Zostera marina en el Mar de Alborán (Mediterráneo Occidental). In: Ballesteros M, Palacin C, Turon X (eds), XIV Simposio Ibérico de Estudios de Biología Marina, Barcelona, Spain, pp 195

Roberts MH, Xie X (1996) Phase relationship between ocular and behavioral circadian rhythms in Bulla gouldiana exposed to different photoperiods. Physiol Behav 59:703-708

Rueda JL (2007) Malacofauna asociada praderas de Zostera marina del Paraje Natural "Acantilados de Maro - Cerro Gordo" (Sur España). Dissertation, University of Málaga, Spain, unpublished

Rueda JL, Fernández-Casado M, Salas C, Gofas S (2001) Seasonality in a taxocenosis of molluscs from soft bottoms in the Bay of Cádiz (southern Spain). J Mar Biol Assoc UK 81:903-912

Rueda JL, Salas C (2003a) Seasonal variation of a molluscan assemblage living in a Caulerpa prolifera meadow within the inner Bay of Cádiz (SW Spain). Estuar Coast Shelf Sci 57:909-918

Rueda JL, Salas C (2003b) Temporal dynamics of molluscan assemblages from soft and bioclastic bottoms in the Strait of Gibraltar. Cah Biol Mar 44:237-248

Rueda JL, Salas C, Marina P (2008) Seasonal dynamics of a deep subtidal Zostera marina L. bed in southern Spain (western Mediterranean Sea). Bot Mar (in press)

Russo GF, Fresi E, Vinci D, Chessa LA (1984) Mollusk syntaxon of foliar stratum along a depth gradient in a Posidonia oceanica (L.) Delile meadow: Seasonal variability. In: Boudouresque CF, Jeudy de Grissac A, Olivier J (eds) International Workshop Posidonia oceanica Beds, GIS Posidonie Publ., pp 311-318

Russo GF, Vinci D, Scardi M, Fresi E (1991) Mollusc syntaxon of foliar stratum along a depth gradient in a Posidonia oceanica bed: 3. A year's cycle at Ischia island. Posidonia Newslett 4:15-25

Sánchez-Jerez P, Barberá-Cebrián C, Ramos-Esplá A (1999) Daily vertical migrations in the epifauna associated with Posidonia oceanica meadows. J Mar Biol Assoc UK 79:971-977

Scipione MB, Gambi MC, Lorenti M, Russo GF, Zupo V (1996) Vagile fauna of the leaf stratum of Posidonia oceanica and Cymodocea nodosa in the Mediterranean Sea. In: Kuo J, Phillips RC, Walker DI, Kirkman H (eds) Seagrass biology: Proceedings of an International Workshop, Rottnest Island, Western Australia, pp 249-260 
Sfriso A, Birkemeyer T, Ghetti PF (2001) Benthic macrofauna changes in areas of Venice lagoon populated by seagrasses or seaweeds. Mar Environ Res 52:323-349

Short FT, Neckles HA (1999) The effects of global climate change on seagrasses. Aquat Bot 63:169-196

Summers WC (1983) Physiological and trophic ecology of cephalopods. In: Russel-Hunter WD (ed) Ecology, The Mollusca. vol. 6, Academic Press, Orlando, pp 261-279

Templado J (1982) Moluscos de las formaciones de fanerógamas marinas en las costas del Cabo de Palos (Murcia). Dissertation, University of Madrid (Complutense), Spain, unpublished

Terlizzi A, Russo GF (1997) The molluscan taxocoenose of differently-exposed Cymodocea nodosa beds: year-long structural patterns and sampling methods. Boll Malac 33:77-82

Thayer GW, Adams SM, LaCroix MW (1975) Structural and functional aspects of a recently established Zostera marina community. In: Cronin LE (ed) Estuarine Research, vol 1, Academic Press, New York, pp 517-540

Thayer GW, Engel DW, Lacroix MW (1977) Seasonal distribution and changes in the nutritive quality of living, dead and detrital fractions of Zostera marina L. J Exp Mar Biol Ecol 30:109-127
Toyohara T, Nakaoka M, Aioi K (1999) Population dynamics and reproductive traits of phytal gastropods in seagrass bed in Otsuchi Bay, north-eastern Japan. P S Z N I: Mar Ecol 20:273-289

Underwood AJ (1997) Experiments in ecology: their logic design and interpretation using analysis of variance. University Press, Cambridge, p 504

Vance DJ (1992) Activity patterns of juvenile penaeid prawns in response to artificial tidal and day-night cycles: a comparison of three species. Mar Ecol Prog Ser 87:215-226

Vance DJ, Heales DS, Loneragan NR (1994) Seasonal, diel and tidal variation in beam trawl catches of juvenile grooved tiger prawns, Penaeus semisulcatus (Decapoda: Penaeidae) in the Embley River, north-eastern Gulf of Carpentaria, Australia. Aust J Mar Fresh Res 45:35-42

Webster PJ, Rowden AA, Attrill MJ (1998) Effect of shoot density on the infaunal macro-invertebrate community within a Zostera marina seagrass bed. Estuar Coast Shelf Sci 47:351-357

Williams SL, Heck KL Jr (2001) Seagrass community ecology. In: Bertness MD, Gaines SD, Hay ME (eds) Marine community ecology, Sinauer Associates Inc, Massachusetts, pp 317-337 